\title{
Organisation of Agriculture*
}

$\mathrm{I}^{\mathrm{T}}$ used to be said that the greatest public benefactor was the man who could make two blades of grass grow where one grew before. Not so to-day, when the nations are considering agreements to restrict output and even destroying the products of the soil. The man of science must take up an apologetic attitude at the present time with regard to agriculture. For two generations he has been entreated to make the land more productive and to reduce costs; but as an American professor of agriculture writes to me: "Ten million acres of cotton and some thousands of tobacco have been ploughed under. The latest move is the killing of some 5 million pigs weighing under $100 \mathrm{lb}$. and the slaughter of some 200,000 prospective mother sows. If this will bring national prosperity I have wasted my life." The man of science may be forgiven if he concludes that he is no longer wanted and may retire to his ivory tower, but whatever food for irony the world spectacle presents he will not be allowed to enjoy it in detachment, for if the deluge comes he will be swept down with the rest.

I propose to inquire a little into the causes of this paradoxical situation. In the first place, the agriculture of the world is predominantly a peasant industry. In Great Britain, we have developed in such an exceptional fashion, for only $6 \cdot 6$ per cent of our workers are engaged on the land, that we do not always realise how much we stand apart. But in France 41 per cent, in Germany 34 per cent, in Czechoslovakia 40 per cent, in Poland 76 per cent, in the United States 26 per cent are so occupied. At the extremity of the scale, in the East, the proportion of the population engaged upon the land may rise to 80 per cent, and in large districts in China even to 90 per cent. Taken alone, these figures do not tell the whole story; more significant is the fact that they are mostly made up of single-handed independent occupiers of land, employing only their own labour and that of their family. In all the European countries except Holland, the independent holders of land outnumber the paid labourers.

The typical English farm is one of about two or three hundred acres carrying half a dozen or so hired labourers. There are, of course, capitalist farms, often of large size, in all countries, as for example the great demesnes of eastern Europe, though the whole trend of policies since the War has been to break these up into single family units.

The advent of science has enormously strengthened the economic position of large-scale capitalist farming, particularly the recent progress in power machinery, of which the full effects have not yet been realised. Efficiency of production has advanced to a degree difficult of estimation; indeed, were agriculture, like any other industry, governed only by the free play of competition in the pursuit of profits, the family farm would long ago have been displaced. But two opposing factors have been at work ; in no old settled country is land a free commodity; custom, even law, tends to perpetuate the old divisions of the land, and the capitalist can rarely buy an area for extensive farming as he can buy a factory site. Despite the increased use of machinery, manual labour is still a large factor in agricultural

* From the Alpxander Pedler lecture of the British Science Guild delivered before the Cambridge Philosophical Society by Sir Daniel Hall, K.C.B., F.R.S., on November 6 . production; the capitalist has to pay for labour, but the peasant does not count his long hours or the assistance of his wife and children.

A century ago the factory did not all at once displace the hand loom, and in the case of agriculture the solitary worker has the additional advantage in the struggle that he is at least producing food for his family. But the final outcome cannot be in doubt; organisation with capital, power and science at command, in other words the machine, must win, provided free competition is allowed to rule.

State organisation of agriculture in some form has become inevitable; many branches of farming in Great Britain would perish if they were not 'nursed'. The question remains, what form shall the organisation take?

We have one example before us in the Russian plan. This represents what we might call an engineer's lay-out to obtain maximum efficiency of production from the land, given a perfectly clean sheet as to land, labour and capital, without any hampering conditions other than those imposed by soil and climate. It is the method of industrial exploitation such as we see at work in some of the great farms of the United States and of tropical countries, raised to a higher power, from thousands to millions of acres, by the all-controlling State organisation. Its aim is to secure from the soil the food and other raw materials required by the nation by the minimum employment of man-power, made effective by the application of science and machinery, thus liberating the greater proportion of the labour hitherto so employed for other forms of production which will add to the real wealth of the community. It demands for its realisation a wealth of directive skill and a technique of national organisation which only began to be attempted during the War. It necessitates a social revolution which no other country is prepared to carry through.

What alternatives are there, methods that will give play to economic efficiency and yet be tender of the initiative and enterprise of the individual ? Can we eventually transform the social structure of the countryside without beginning by breaking it ? In the organisations that have been set up to bring the producers of each commodity into selling corporations, we see the beginnings of such a system. It is perhaps not generally realised how fundamental a change in the conduct of the agricultural industry of Great Britain has been wrought by recent legislation. Provided a certain proportion of the producers of a given commodity demonstrate their case to the Minister of Agriculture, he can give to their combination a monopoly of the right of sale; no producer outside the combination may sell to the public, all the members of the combination must sell through it. These powers of combination and control can be extended to any intermediary manufacturing process intervening between the producer and the retailer; prices will be fixed and production regulated by the limitation the corporation will put on the amounts it will sell for each producer. The power to determine internal prices will ultimately depend on the regulation of the volume of imports and the duties that are to be imposed. The Government has undertaken to apply one or other of these measures as a necessary part of the new policy to stimulate home production. The 
object is to ensure stable prices, no longer subject to the devastating influence of foreign competition, often forced and illegitimate. In brief, producers and processors of any agricultural commodity can now form a guild, which will be endowed with a monopoly, and directly or indirectly will exercise complete control of all production for sale.

The organisation aims at removing the great criticism that can be levelled against the agricultural community, that its average practice is much below the performance of the best farmers. In future, if a farmer is to sell pigs at all he will have to forgo many of his preferences for particular breeds or methods of feeding, and to bring forward pigs that have been bred and fed on the lines laid down by the corporation, on instructions that are the outcome of knowledge and experiment. Hitherto such knowledge, in so far as research has made it available, has been left to permeate by means of advice, but the results have always been slow and imperfect because the economic advantage of the improved method is generally of an order that is easily obscured by the accidentals of farming, especially as accurate recording has not been common practice. Such a co-operative but controlled organisation is the only one I can see that can compete with the Russian plan of complete unification of the industry, and at the same time retain the essential freedom of the individual.

Such corporations will be able and, if they are to be acceptable, will have to enforce certain reformations in their particular industry which may not be of any great profit to the farming community but may be required by the consumers. To state one such case, it is possible to free the dairy herd of the country from bovine tuberculosis, which would not only mean greater safety to the health of the general population but also would cheapen the production of milk by reducing one of the considerable items of cost-the relatively short life of the average dairy cow. In so far as the milk producers as a body have to be paid for the costs of production, whatever they may be, no gain to them would accrue by the elimination of tuberculosis ; the new cheapness would be passed on to the consumers. The controlling corporation, which must consider the interests of the general public because from them it derives its monopoly and price-fixing power, can embark upon such a scheme. It can take the long: view and adopt a scheme which despite its prime cost will ultimately both cheapen and improve the product.

It is indeed a necessary part of the new system, if these corporations are to become efficient elements of the national economy, that there should be some superior organisation planning and directing their work in the national interest. Otherwise the corporations may easily degenerate into guilds concerned only in maintaining a price-level that will enable their members to carry on automatically on the old lines. It would be for this central body, personified in the Minister of Agriculture, to decide which branches of the agricultural business in Great Britain should be encouraged to develop and which should be subjected to the brunt of economic pressure, whereby they would be either transformed or abandoned. To take an example, it is inevitable that there will be, in the future as in the past, strong pressure from an important section of farmers to maintain a remunerative price for wheat. Now while wheat may be almost a necessary element in the current rotation on certain types of English soil, it should be regarded as a by-product rather than as the main object of the farming system. For our farming can and should pick and choose, specialising upon the higher grade products rather than on the primary commodities like wheat. Considering the ratio that our land fit for cultivation bears to our population, we cannot be self-supporting as regards food, except at fantastic cost or by reducing excessively the standard of living. In Western agriculture as at present carried on, two acres and upwards of land are employed in producing the food, etc., consumed by one unit of the population. Since in round figures the cultivated area in Great Britain is only $\mathbf{4 5}$ million acres, to provide for an approximate population of 45 million, it will be seen that the land available is far from sufficient except under an intensification of production that is impracticable.

The fundamental truth is that; whatever may be the increased efficiency of production that science has put at man's disposal, it will be still insufficient to satisfy the reasonable demands of the population, when each in turn is producing some commodity that can be freely exchanged. It is precisely in this difficulty of exchange that the plight of the agriculturist resides, all the world over, and if we take a world point of view, we see that agriculture cannot lift itself out of its depression by its own efforts. Farmers are the primary producers, the first sellers in the chain of commerce, but they are waiting upon a renewal of the power to buy on the part of their customers, that is, the industrialists and the people at large. Whatever may be our power to revive British agriculture, because within our borders there is such an immense margin between our actual production and our consumption, yet world agriculture cannot revive until the wheels of international trade begin to go round more freely.

\section{Combustion of Hydrocarbons}

$A^{\mathrm{s}}$ the outcome of much controversy towards the end of last century, former erroneous notions of a preferential burning whether of hydrogen or of carbon in hydrocarbon combustion were finally overthrown and the way opened for now interpretations of the mechanism of the process; and more particularly for one, originally suggested by $\mathrm{H}$. E. Armstrong so far back as 1874, namely, that its successive stages involve the transient formation of unstable hydroxylated molecules which, according to circumstances, decompose more or less rapidly under the influence of heat, giving rise to simpler intermediate products, and finally to steam and oxides of carbon.

As was shown by Prof. W. A. Bone in a public lecture arranged by the Chemical Society and delivered at the Royal Institution on October 19, this view has been substantiated by the results of the systematic researches of his collaborators and himself upon the slow combustion of hydrocarbons (but chiefly methane, ethane, propane, ethylene and acetylene) from 1898 up to the present day. These 